\title{
Cover crops as the main element of biologization of agriculture in the no-till system for reproduction of soil fertility
}

\author{
Olga Tomashova ${ }^{1, *}$, Nicolay Osenniy ${ }^{1}$, Suleyman Abdurashytov ${ }^{2},{\text { Aleksandr } \text { Ilyin }^{1} \text {, and }}^{2}$ \\ Lubov Veselova ${ }^{1}$ \\ ${ }^{1}$ V. I. Vernadsky Crimean Federal University, 295492, prosp. Vernadskogo, 4, Simferopol, Russia \\ ${ }^{2}$ FSBSI "Research Institute of Agriculture of Crimea", 295493, 150 Kievskaya str., Simferopol, \\ Russia
}

\begin{abstract}
The goal is to develop the main elements of biologization of the No-till system in the conditions of the Piedmont-steppe zone of Crimea, to study the effect of various types of ground cover crops on soil fertility, yield and grain quality of agricultural crops in conditions of insufficient and unstable moisture. When intermediate crops were cultivated as ground cover crops in the No-till system, the available moisture reserves in the meter layer were at a satisfactory level after vetch cultivation $-107.6 \mathrm{~mm}$ and in the control (without ground cover crops) $-99.6 \mathrm{~mm}$. The highest yield of green mass of ground cover crops was in all variants with the use of multicomponent mixtures, which was 2 or more times higher than the yield of intermediate ground cover crops from 1-2 and 3 spring crops and almost 10 times higher than that of winter rye. This made it possible to fix $30-33 \mathrm{~kg}$ of nitrogen, 4-5.9 $\mathrm{kg}$ of phosphorus and $13.9-16.7 \mathrm{~kg}$ of potassium in plants and in the root system annually by the end of the growing season of spring crops per hectare of sowing.
\end{abstract}

\section{Introduction}

Soil fertility management, which consists in regulating soil processes in order to ensure optimal parameters of the main factors of plant life in the long term, is a key task of agriculture.

Biologization of agriculture allows solving the problem of reproduction of soil fertility, providing optimal conditions for the growth and development of agricultural plants in order to obtain high yields due to the activation of biological factors, those that determine soil fertility. In numerous studies, the authors confirm our conclusion about the positive dynamics of the influence of the No-till (NT) system on soil fertility and organic matter content. No-till increased the organic matter content of soil C (28\%) and earthworms (5 times) compared to conventional tillage (CT). The use of rye (Secale cereale L.) instead of Vicki (Vicia villosa Roth.) as a cover crop under NT, it reduced N2O and increased yield. $\mathrm{N} 2 \mathrm{O}$ emissions decreased by $51 \%$ at NT compared to CT in well-drained silt-clay soils [1].

${ }^{*}$ Corresponding author: 777tom@bk.ru 
In other studies, organic carbon did not change after 13 years of no-till implementation. Organic N, P, Ca improved under NT conditions. PH declined when using NT, but was in a positive range for corn production. Corn yields also increased at no-till, but only at higher $\mathrm{N}$ fertilizer rates [2]. Accumulation of total organic carbon and total $\mathrm{N}$ in surface soil with cover crops was observed, with concentrations of total organic carbon higher in the heavy fraction $(79.0 \%)$ than in the light fractions $(21.0 \%)$. Although the carbon content changed little during the two years of this experiment [3].

No-till provided more soil organic carbon storage in Western canadian conditions. The rate of carbon gain with NT decreased over time. Soil texture affects the rate of carbon change at NT [4].

Other studies have shown that reducing soil disturbance improves the physical protection of organic carbon, soil structure, and infiltration, but it has also been shown that total carbon takes time to improve continuous maize cultivation in the studied soil [5].

No-till and high $\mathrm{C}$ input are key to avoid soil degradation in newly irrigated areas. NT avoids soil crust formation, securing corn yield [6].

A number of studies have shown a significant influence of soil tillage on various physical, chemical and biological parameters. The calculated indicator of soil quality was significantly higher in soil without tillage than in conventional tillage [7]. However, over the years, landless farming has increased the content of solid particles of organic carbon in the soil, associated with minerals of organic matter and humin due to the constant flow of plant residues to the surface layers [8].

Soils with No-till almost doubled the mass of large macroaggregates and tripled the content of $\mathrm{C}$ and $\mathrm{N}$ in this fraction of water-resistant aggregates compared to the traditional tillage system $[9,10]$. The long absence of tillage contributed to macroaggregation in the surface soil. No-till led to the appearance of C-enriched microaggregates on the soil surface [11].

The relative ratio of yields at NT and CT was correlated with the aridity index (Ai) for different cultivation systems and residue management strategies. No-till did better with lower Ai values. When the yield of NT and CT was the same, the Ai value was defined as the threshold value of $\mathrm{Ai}$, and this value turned out to be highly dependent on crop management [12].

The results of many studies show that NT has great potential as a measure to mitigate soil erosion with a significant reduction in soil losses in agricultural fields, which have a potential beneficial effect on precipitation and phosphorus $(\mathrm{P})$ particulates entering water bodies. However, NT increased the loss of dissolved reactive phosphorus and had little effect on nitrogen $(\mathrm{N})$ leaching, limiting the overall positive effect on water purification $[13,14]$. Model modeling has shown that no-till itself has little effect on erosion processes and that additional measures are needed to increase vegetation cover to significantly reduce sediment transport in these agricultural areas [15].

\section{Materials and methods}

On the experimental field of the Agrotechnological Academy was based 2 experiments with one element for each one in three-time repetition on the cultivation of ground cover crops in no-till system in intermediate crops after harvesting winter wheat and winter barley. Cultivation of winter wheat and winter barley was carried out in 4 complete crop rotations with the following alternation of crops:
1) peas
2) winter wheat + intermediate crops (cover crops)
3) corn
4) winter barley 
Winter wheat Nador and winter barley Luran were sown annually during 1-2 days of October with norm of 2.2-2.5 million pieces/ha.

Peas Pharaon was sown in the 2-3 decade of March with norm 1, 2 million pieces/ha.

The sowing of the above crops in crop rotation on the experimental field was carried out using the seeder G-114 - a direct seeder seeding production of the Gerardi plant (Argentina).

Corn (Berta hybrid) was sown annually on April 25 with the norm 60 thousand pieces/ha using the seeder Sigma 5 (Italy).

Experiment № 1. The study of the influence of cover crops was conducted in crop rotation link: winter wheat-corn (in crop sowing after harvesting wheat).

Experience options:

Option 1: no-till system + Winter Rye stubble ground cover seeding

Option 2: no-till system + Winter Rape stubble ground cover seeding

Option 3: no-till system + Winter Vicia stubble ground cover seeding

Option 4: no-till system + Winter Rye + Winter Rape stubble ground cover seeding

Option 5: no-till system + Winter Rye + Vicia stubble ground cover seeding

Option 6: no-till system + Winter Rape + Vicia stubble ground cover seeding

Option 7: no-till system + Winter Rye + Winter Rape + Vicia stubble ground cover seeding

Option 8: no-till system + Oats stubble ground cover seeding

Option 9: no-till system + Radish stubble ground cover seeding

Option 10: no-till system + Oats + Radish stubble ground cover seeding

Option 11: no-till system + Oats + Vicia stubble ground cover seeding

Option 12: no-till system + Radish + Vicia stubble ground cover seeding

Option 13: no-till system + Oats + Radish + Vicia stubble ground cover seeding

Option 14: no-till system + stubble ground cover seeding mixture of 5 crops (corn + pea + flax + sunflower + millet)

Option 15: no-till + stubble ground cover seeding mixture of 8 crops $($ corn + peas + flax + sunflower + millet + radish + mustard + vicia)

Option 16: no-till system + stubble ground cover seeding mixture of 11 crops (corn + peas + flax + sunflower + millet + radish + mustard + vicia + switchgrass + lentils + buckwheat $)$

Option 17: no-till system + stubble ground cover seeding mixture of 13 crops (corn + peas + flax + sunflower + millet + radish + mustard + vicia + switchgrass + lentils + buckwheat + oats + melilot $)$

Option 18: no-till system without stubble ground cover seeding (control - №1)

Option 19: Traditional soil treatment system without stubble ground cover seeding (control - № 2)

The area of the experimental section (one crop rotation field) is 1,5 hectares.

The area of the elementary plot is $150 \mathrm{~m}(25 \mathrm{~m} \mathrm{x} 6 \mathrm{~m})$

Experiment 2. The study of the cover crops influence was conducted in crop rotation link: winter barley-peas (in crop sowing after harvesting barley). Experience options completely duplicate the scheme presented in experiment № 1 .

In 2018 in the foothill-steppe zone of Crimea after the harvesting winter crops for grain (wheat, barley) from the third decade of June till the first decade of September $188.5 \mathrm{~mm}$ of precipitation fell. This amount of precipitation exceeds the rate of $30-80 \mathrm{~mm}$, which is necessary for ground cover crops growing. The experimental plots were sown on July 3 after winter wheat harvesting. In 2019 after harvesting winter crops for grain (wheat, barley) from the third decade of June till the first decade of September $166.9 \mathrm{~mm}$ of precipitation fell. Experimental plots of land after winter barley harvesting were sown on July 2, after winter wheat - on July 17.

In 2019 groundcover crops have been growing in the Field № 25 (after wheat) and in the Field № 22 (after barley). Winter barley Luran variety was sown on October 19 in 2018 
with a norm of 2.25 million pieces ha. The predecessor was corn. Due to heavy rainfall and hail on June 5, 2019, the greatest yield losses were on the field of winter barley Luran variety. The winter barley's windfall which sprang up in a short time, created serious competition both for cultivated plants and weeds.

Visualization of the development of mycorrhiza in field crops was carried out by staining the root sections with black ink. The assessment of mycorrhization was studied quantitatively under a stereomicroscope according to the Travlo method. Statistical data processing was carried out according to Dospekhov using the Excel software package.

\section{Results and discussion}

Southern carbonate low-humus chernozems of medium thickness, formed on red-brown Pliocene clays and yellow-brown forest-like loams, usually have a loose humus horizon, silty-silty structure. As a result of anthropogenic impact on the soil in the form of mechanical soil cultivation or the periodic absence of any vegetation on its surface, in combination with soil cultivation, lead to irreversible degradation processes, closely related to the deterioration of its agrophysical properties.

In our studies, the cultivation of intermediate ground cover crops in the summer period made it possible to preserve the main agrophysical indicators of the fertility of the arable layer of the southern carbonate low-humus chernozems at the optimum level during the growing season of these crops. The density of the soil, which was determined by the volume-weight method using steel rings, ranged from $1.18 \mathrm{~g} / \mathrm{cm} 3$ to $1.28 \mathrm{~g} / \mathrm{cm} 3$, i.e. soil overconsolidation was not detected in any of the studied areas. Cultivation of vetch in a pure form ensured the preservation of satisfactory reserves of available moisture in a meter layer of soil. The optimal number of pores in the arable layer was observed on three variants of ground cover crops - winter rapeseed + vetch $(55.0 \%)$, oil radish $(56.2 \%)$ and a mixture of five crops $(55.6 \%)$ : corn + peas + flax + sunflower + lentils [16]. The optimal ratio of capillary and non-capillary pores was formed under vetch, oats and radish, as well as a mixture of oats, radish and vetch. Among winter ground cover crops, the most favorable soil structure was formed when growing 2-component mixtures using winter rape, both in combination with winter rye and winter vetch. Among the spring ground cover crops, the formation of an optimal ratio of agronomically valuable soil aggregates was provided by radish with oats and a 3-component mixture (radish + oats + vetch).

Among winter crops, when grown after winter wheat, the lowest yield was shown by plot № 1 - winter rye $(1.2 \mathrm{t} / \mathrm{a})$. At the same time, according to the results of analysis of variance, the given yield data are leveled on average for 2 years (Table 1., Table 2., Table 3.).

Table 1. Yield of winter ground cover crops (stubble sowing after winter wheat), centner / ha

\begin{tabular}{|l|c|c|c|}
\hline \multicolumn{1}{|c|}{ Option } & 2018 year & 2019 year & $\begin{array}{c}\text { Average for } \\
\text { 2 years }\end{array}$ \\
\hline 1. Winter cover rye & 6,4 & 18,4 & 12,4 \\
\hline 2. Winter rape & 33,9 & 27,2 & 30,6 \\
\hline 3. Winter vicia & 30,6 & 3,4 & 17,0 \\
\hline 4. Winter cover rye + winter rape & 72,0 & 33,6 & 52,8 \\
\hline 5. Winter cover rye + vicia & 15,3 & 7,2 & 11,3 \\
\hline 6. Winter rape + vicia & 36,3 & 24,8 & 30,6 \\
\hline $\begin{array}{l}\text { 7. Winter cover rye + winter rape + } \\
\text { vicia }\end{array}$ & 26,2 & 18,4 & 22,3 \\
\hline
\end{tabular}




\begin{tabular}{|c|c|c|c|}
\hline $\mathrm{SSD}_{05}$ & 11,2 & 28,8 & $\mathrm{~F}_{\mathrm{V}}<\mathrm{F}_{05(\mathrm{~V})}$ \\
\hline
\end{tabular}

Among the options with winter crops as cover crops in 2018, the maximum yield of green mass was noted on option № 4 Winter rye from Lake Rapeseed $(72.0 \mathrm{c} / \mathrm{ha})$, among spring crops - option № 10 Oats with Radish $56.5 \mathrm{c} /$ ha of green mass (table 2). The highest yield of ground cover crops when growing them after winter wheat was obtained according to the options using 5,8 and 10 component mixtures for sowing - № 14, 15 and 16 (from 108 to $122 \mathrm{c} / \mathrm{ha}$ ). The maximum yield of green mass of cultivated plants, in general, according to the experience, was formed on option № 14, a mixture of 5 cover crops $($ corn + peas + flax + sunflower + lentils $)-139.3 \mathrm{c} /$ ha (table 3$)$.

Among winter crops and their mixtures in 2019 , the yield was approximately the same. It ranged from 3.4 to 33.6 centners per hectare, while the maximum indicator was at the lake. rye from the lake. rapeseed (33.6), and the minimum for Vika (3.4) with $\mathrm{SSD}_{05}$ (28.8). You should not sow Vika in its pure form. Over the course of two years, it was found that, on average, the combination of the lake. rye + lake. rapeseed (52.8). It is also worth paying attention to the cultivation of the lake. rapeseed in its pure form (30.6) and a mixture of the lake. rapeseed + vetch (30.6).

Table 2. Yield of spring ground cover crops (stubble after winter wheat), c / ha

\begin{tabular}{|l|c|c|c|}
\hline \multicolumn{1}{|c|}{ Option } & 2018 year & 2019 year & $\begin{array}{c}\text { Average for 2 } \\
\text { years }\end{array}$ \\
\hline 8. no-till + cover oat & 31,6 & 65,4 & 48,5 \\
\hline 9. no-till + cover radish & 38,1 & 62,4 & 50,3 \\
\hline 10. no-till + cover oat + radish & 56,5 & 58,0 & 57,3 \\
\hline 11. no-till + cover oat + vicia & 33,4 & 52,6 & 43,0 \\
\hline 12. no-till + cover radish + vicia & 35,1 & 50,3 & 42,7 \\
\hline $\begin{array}{l}\text { 13. no-till + cover oat + radish + } \\
\text { vicia }\end{array}$ & 28,8 & 82,0 & 55,4 \\
\hline \multicolumn{1}{|c|}{$\mathrm{SSD}_{05}$} & 11,2 & 28,8 & $\mathrm{~F}_{\mathrm{V}}<\mathrm{F}_{05(\mathrm{~V})}$ \\
\hline
\end{tabular}

Among spring crops, the options for sowing one and two crops ensured the yield of green mass at the level of $31.6-56.5 \mathrm{c} /$ ha, the difference between which exceeded the NSR05 experiment $=11.2 \mathrm{c} /$ ha. The next year fluctuated within the allowed $50.3-65.4 \mathrm{c} /$ ha with NSR05 $28.8 \mathrm{c} /$ ha, which is within the limits. The three-component mixture (plot No. 13 - Oats + Radish + Vika), due to the best interaction of plants in agrophytocenosis, provided a yield of $82.0 \mathrm{c} / \mathrm{ha}$, which is $30-32 \mathrm{c} /$ ha higher than for 11 and 12 options with $\mathrm{HCP} 05=28,8 \mathrm{c}$.

So in 2018, the period of maximum precipitation fell in July, when all experiments had already been sown, but in 2019, the maximum amount of summer rain fell in June, which prevented sowing from being carried out until free moisture evaporated from the upper layer. But for each individual year, in the context of plots with the use of various crops as ground cover, an impact on their yield was noted.

Table 3. The yield of multicomponent mixtures of ground cover crops (after winter wheat), c/ha

\begin{tabular}{|c|c|c|c|}
\hline Option & 2018 year & 2019 year & On average for 2 years \\
\hline 14. Mix of 5 cultures & 139,3 & 103,1 & 121,2 \\
\hline 15. Mix of 8 cultures & 42,8 & 201,6 & 122,2 \\
\hline 16. Mix of 10 cultures & 27,8 & 188,8 & 108,3 \\
\hline
\end{tabular}




\begin{tabular}{|c|c|c|c|}
\hline 17. Mix of 13 cultures & 48,7 & 86,4 & 67,6 \\
\hline $\begin{array}{c}\text { Average from the } \\
\text { experience }\end{array}$ & 41,3 & 63,7 & 52,5 \\
\hline $\mathrm{SSD}_{05}$ & 11,2 & 28,8 & $\mathrm{~F}_{\mathrm{V}}<\mathrm{F}_{05(\mathrm{~V})}$ \\
\hline
\end{tabular}

On average, for 2 years, the yield of multicomponent mixtures was within 67.6-122.2 c/ ha $(\mathrm{FV}<\mathrm{F} 05(\mathrm{~V}))$, and the maximum value of $122.2 \mathrm{c} /$ ha was recorded according to option No. 15 (Mix of 8 cultures). It should be noted that in 2018 the lowest yield of green mass, $27.8 \mathrm{c} /$ ha, was formed according to option № 16 (Mix of 11 crops). The maximum value (139.3 c / ha) of this indicator was noted for option № 14 (a mixture of 5 crops), with $\mathrm{SSD}_{05}=11.2 \mathrm{c} /$ ha. Multicomponent mixtures of 5, 8 and 11 crops in 2019 provided yields at 103.1, 201.6 and $188.8 \mathrm{c} / \mathrm{ha}$, respectively. The maximum yield of green mass, at the same time, both among multicomponent mixtures, and in general, according to experience, was formed on option 15 - a mixture of 8 crops for stubble crops (corn + peas + flax + sunflower + radish + mustard + lentil + buckwheat $)-201.6$ centner / ha, while the maximum weight of green mass was provided by sunflower and rare oilseed.

According to experiment № 2, after winter barley, on average over the years of research, the maximum yield of green mass of ground cover crops (from 48.1 to $66.1 \mathrm{c} / \mathrm{ha}$ ) was observed in the variants using multicomponent mixtures (№ 15, 16, 17), which in The yield of intermediate ground cover crops from 1-2 and 3-component mixtures of spring crops was 2 times higher.

Analyzing the structure of the yield of ground cover crops, taking into account weeds, the predecessor of which was a field of winter barley (in 2018, this is field no. 24), we took into account the mass of cultivated and weed plants, where the largest indicator of the mass of cultivated plants among winter and spring crops (1-3 crops) provided option No. 8 (oats) - $64.9 \mathrm{c} / \mathrm{ha}$ ). The smallest indicator was in option №. 2 - (lake rapeseed) - 14.6 (table 4.) c / ha, as well as in options No. 6 (winter rapeseed + vetch) - 18.4 and № 12 (radish + vetch ) - 18.1 centner / ha, with an $\mathrm{SSD}_{05}$ of 7.5 centner / ha (table 5.).

Table 4. The yield of winter ground cover crops (after winter barley in comparison with winter wheat), 2018, c/ha

\begin{tabular}{|l|c|c|c|}
\hline \multicolumn{1}{|c|}{ Option } & $\begin{array}{c}\text { After winter } \\
\text { wheat }\end{array}$ & $\begin{array}{c}\text { After } \\
\text { winter } \\
\text { barley }\end{array}$ & $+/-$ \\
\hline 1. no-till + winter cover rye & 6,4 & 20,0 & $<13,6$ \\
\hline 2. no-till + winter rape & 33,9 & 14,6 & $>19,3$ \\
\hline 3. no-till + winter cover vicia & 30,6 & 35,7 & $<5,1$ \\
\hline 4. no-till + winter cover rye + winter rape & 72,0 & 15,5 & $<56,5$ \\
\hline 5. no-till + winter cover rye + vicia & 15,3 & 15,7 & $<0,4$ \\
\hline 6. no-till + winter cover rape + vicia & 36,3 & 18,4 & $>17,9$ \\
\hline 7. no-till + winter cover rye + rape+vicia & 26,2 & 21,8 & $>4,4$ \\
\hline
\end{tabular}

Accordingly, when taking into account weeds, we determined the highest indicator of the mass of weeds in option No. 1 (winter rye) and No. 2 - (Lake Raps) - 71 and 37.7 centners / ha, respectively; also in option No. 6 (winter rapeseed + vetch) $-40.1 \mathrm{c} / \mathrm{ha}$; No. 12 (radish + vetch) - $39.6 \mathrm{c} / \mathrm{ha}$, with the NSR $14.4 \mathrm{c} /$ ha, and the least weight of weeds was noted according to option No. 8 (oats) $-12.7 \mathrm{c} /$ ha, which is 5.1 times less mass of cultivated plants. And in terms of the quantitative ratio of cultivated and weed plants, plot No. 8 with oats sown in pure form had an advantage over other variants of the experiment. 
Table 5. The yield of spring ground cover crops (after winter barley in comparison with winter wheat), 2018, c/ha

\begin{tabular}{|l|c|c|c|}
\hline \multicolumn{1}{|c|}{ Option } & $\begin{array}{c}\text { After winter } \\
\text { wheat }\end{array}$ & $\begin{array}{c}\text { After } \\
\text { winter } \\
\text { barley }\end{array}$ & $+/-$ \\
\hline 8. no-till + cover oat & 31,6 & 64,9 & $<33,3$ \\
\hline 9. no-till + cover radish & 38,1 & 24,2 & $>13,9$ \\
\hline 10. no-till + cover oat + radish & 56,5 & 34,0 & $>22,5$ \\
\hline 11. no-till + cover oat + vicia & 33,4 & 44,6 & $<11,2$ \\
\hline 12. no-till + cover radish + vicia & 35,1 & 18,1 & $>17,0$ \\
\hline 13. no-till + cover oat + radish + vicia & 28,8 & 24,4 & $>4,4$ \\
\hline
\end{tabular}

From Table 5. it can be said that in 2018 the difference between crops of winter barley and winter wheat was significant. The greatest difference was shown by the two-component mixture of the lake. rye from the lake. rapeseed, where the difference $(56.5 \mathrm{c} / \mathrm{ha})$ is fixed in favor of winter wheat. The smallest difference was shown by the mixture of the lake. rye $+\operatorname{vetch}(0.4 \mathrm{c} / \mathrm{ha})$

The ratio of spring crops after winter wheat and winter barley in 2018 indicates significant fluctuations in all variants, with the exception of the three-component mixture Oats + Radish + Vika, the difference of which varies within $4.4 \mathrm{c} /$ ha. The greatest difference was produced by barley over wheat in variant 8 (Oats $33.3 \mathrm{c} / \mathrm{ha}$ ). Wheat, however, had an advantage over barley as a predecessor for option №10 Oats + Radish $(22.5 \mathrm{c} / \mathrm{ha})$.

Among the multicomponent mixtures (table 6.) the greatest difference in yield was provided by plot №. 14 - mix of 5 crops, where, after winter wheat, $139 \mathrm{c} /$ ha were obtained, and winter barley $-86.9 \mathrm{c} /$ ha. The difference between the predecessors was 56.8 $\mathrm{c} / \mathrm{ha}$ in favor of wheat.

Table 6. The yield of multicomponent spring mixes (after winter barley in comparison with winter wheat), 2018, c/ha

\begin{tabular}{|l|c|c|c|}
\hline \multicolumn{1}{|c|}{ Option } & $\begin{array}{c}\text { After winter } \\
\text { wheat }\end{array}$ & $\begin{array}{c}\text { After } \\
\text { winter } \\
\text { barley }\end{array}$ & $+/-$ \\
\hline $\begin{array}{l}\text { 14. no-till + cover } \\
\text { (corn+pea+flax+sunflower+lentil) }\end{array}$ & 139,3 & 86,9 & $>56,8$ \\
\hline 15. Mix of 8 cultures & 42,8 & 66,1 & $<23,3$ \\
\hline 16. Mix of 10 cultures & 27,8 & 48,1 & $<20,3$ \\
\hline 17. Mix of 13 cultures & 48,7 & 76,5 & $<27,8$ \\
\hline
\end{tabular}

All other variants of multicomponent mixtures of ground cover crops after winter barley have an advantage in obtaining a yield at the level of 20.3-27.8 $\mathrm{c} /$ ha in comparison with winter wheat. Thus, winter crops when grown in intermediate ground cover crops in 1-, 2and 3-component mixtures provided a yield of green mass 1.8-2.1 times less than spring crops, and 3.6-4.1 times less multicomponent spring mixtures consisting of 5-, 8-, 10- and 13 -crops. When the maximum possible biomass of spring crops was obtained in the conditions of the Piedmont-steppe zone of Crimea, by the end of their growing season, 30$33 \mathrm{~kg}$ of nitrogen, 4-5.9 $\mathrm{kg}$ of phosphorus and 13.9-16.7 kg were recorded in the aboveground part of plants and in the root system potassium per hectare of crops.

In the soils of Crimea, there are large indigenous populations of arbuscular mycorrhizal (AM) fungi. The effectiveness of many indigenous AM fungi is not sufficient to create 
productive symbiosis, which can be achieved by breeding for this trait with target plants [17].

The objects of research are a combination (joint sowing) of cover crops: common oats Avena sativa L., vetch Vicia sativa L., oil radish Raphanus sativus var. oleifera Metzg., an association of AM fungi from the Crimean collection of microorganisms (http://www.ckprf.ru/usu/507484/). An inoculum based on AM fungi with a load of at least 20 colonizing units per seed was applied together with the seeds.

According to the results of this year, significant differences in the development of arbuscular mycorrhiza in the roots of the studied plants were observed. These differences were found depending on the species of plant. In the variant with three cover crops oats+vetch+radish, it was shown that the vetch roots are densely populated by mycorrhizal fungi. The indicators of mycorrhizal colonization (MC) inside the roots: frequency of occurrence, development intensity and arbuscules abundance were significantly high (Fig. 1, Table 7). The introduction of the AM fungi inoculum did not affect these parameters, because it's probably the highest possible level of such indicators of MC for a given crop.

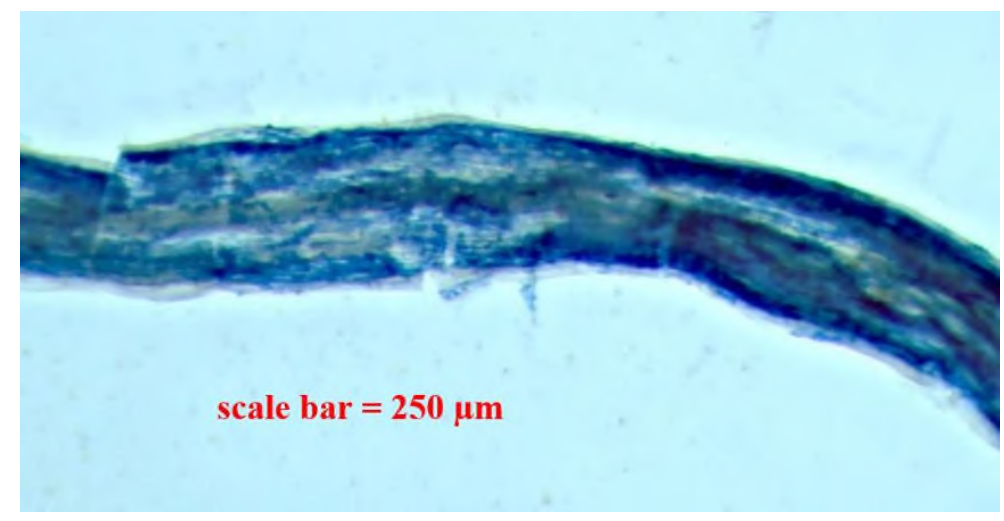

Fig. 1. Mycorrhizal colonization of vetch roots. The mycelium and arbuscules of the fungus are colored blue inside the root.

Table 7. The level of mycorrhizal colonization (MC) of some cover crops using the association of AM fungi (southern chernozem, field experiment against the background of indigenous races of mycorrhizal fungi, 2019)

\begin{tabular}{|c|c|c|c|c|}
\hline $\begin{array}{l}\text { Variant of } \\
\text { study }\end{array}$ & $\begin{array}{c}\text { Frequency of } \\
\text { occurrence of } \\
\text { MC, \% }\end{array}$ & $\begin{array}{c}\text { Intensity of } \mathrm{MC} \\
\quad \% \mathrm{~cm}^{-1} \text { root }\end{array}$ & $\begin{array}{l}\text { Arbuscules } \\
\text { abundance, } \\
\% \mathrm{~cm}^{-1} \text { root }\end{array}$ & $\begin{array}{c}\text { Vesicles } \\
\text { abundance, } \\
\% \mathrm{~cm}^{-1} \text { root }\end{array}$ \\
\hline Vetch + AMF & $96,7 \pm 3,3$ & $80,2 \pm 3,4$ & $51,8 \pm 3,6$ & $2,6 \pm 0,1$ \\
\hline Vetch w/t & $96,4 \pm 3,6$ & $76,7 \pm 5,6$ & $54,5 \pm 0,8$ & $2,4 \pm 1,4$ \\
\hline Oat + AMF & $85,3 \pm 7,5$ & $32,6 \pm 2,0$ & $14,8 \pm 2,1$ & $0,6 \pm 0,2$ \\
\hline Oat w/t & $95,8 \pm 4,2$ & $25,8 \pm 1,2$ & $3,8 \pm 1,3$ & $0,8 \pm 0,1$ \\
\hline
\end{tabular}

Notes: w/t - control without AMF treatment; $\mathrm{F}_{\text {critical }}>3$

At the same time, oat plants showed a significant increase in the intensity of MC by $6.8 \%$, and the arbuscules abundance by 3.9 times when using AMF (Fig. 2, Table 1). The introduction of mycorrhizal fungi did not affect the vesicles development. Arbuscules and vesicles are new organelles formed during the effective symbiosis by AM fungi and plants. Arbuscules are formed by a symbiotic system of both partners for the exchange of nutrients between them. Vesicles are organelles that store sugars obtained from plants and other substances. Therefore, an increase in the MC intensity and the arbuscules abundance in oat 
roots in the variant with the use of mycorrhizal association could contribute to an intensification in the exchange of nutrients between symbiotic partners and a better accumulation of plant biomass.

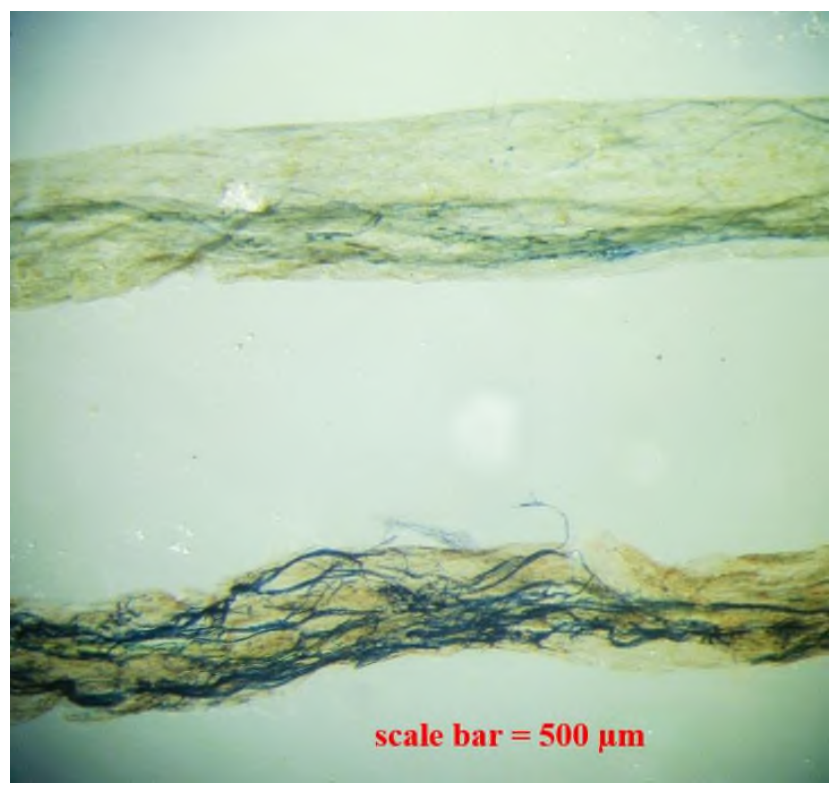

Fig. 2. Mycorrhizal colonization of oat roots. The mycelium and arbuscules of the fungus are colored blue inside the root. The segment at the top is the minimum intensity of colonization, at the bottom is the maximum.

According to the literature oil radish does not form mycorrhiza, like all members of the Brassicaceae family, therefore, its mycorrhization has not been studied. During the symbiosis of AM fungi and plants from a multicomponent mixture (option №. 17) with simultaneous sowing of 13 cover crops, where 8 mycorrhizating plant species were present, an improvement in root mycorrhization was observed in oats, lentils, flax and sunflower. Decreased colonization - in vetch, peas and corn.

The enhancement of biological activity under such crops as oats and vicia is confirmed by additional experience, which was carried out by us by the method of application of linen cloths. This method showed the intensity of the main process - cellulolytic activity, which was determined by the gravimetric method according to the decrease in weight of linen sheets buried in the soil to a depth of arable horizon $(0-30 \mathrm{~cm})$ for a period of 1 month. At the same time, we found that in the severely arid conditions of 2019, the greatest biological activity of the soil was manifested in the experimental plots under the cover of such crops as oats and vetch. In the variant with the use of vetch, the greatest activity of the soil biota is manifested when it is grown in a mixture with rye - variant No. 5 (Fig. 3). 


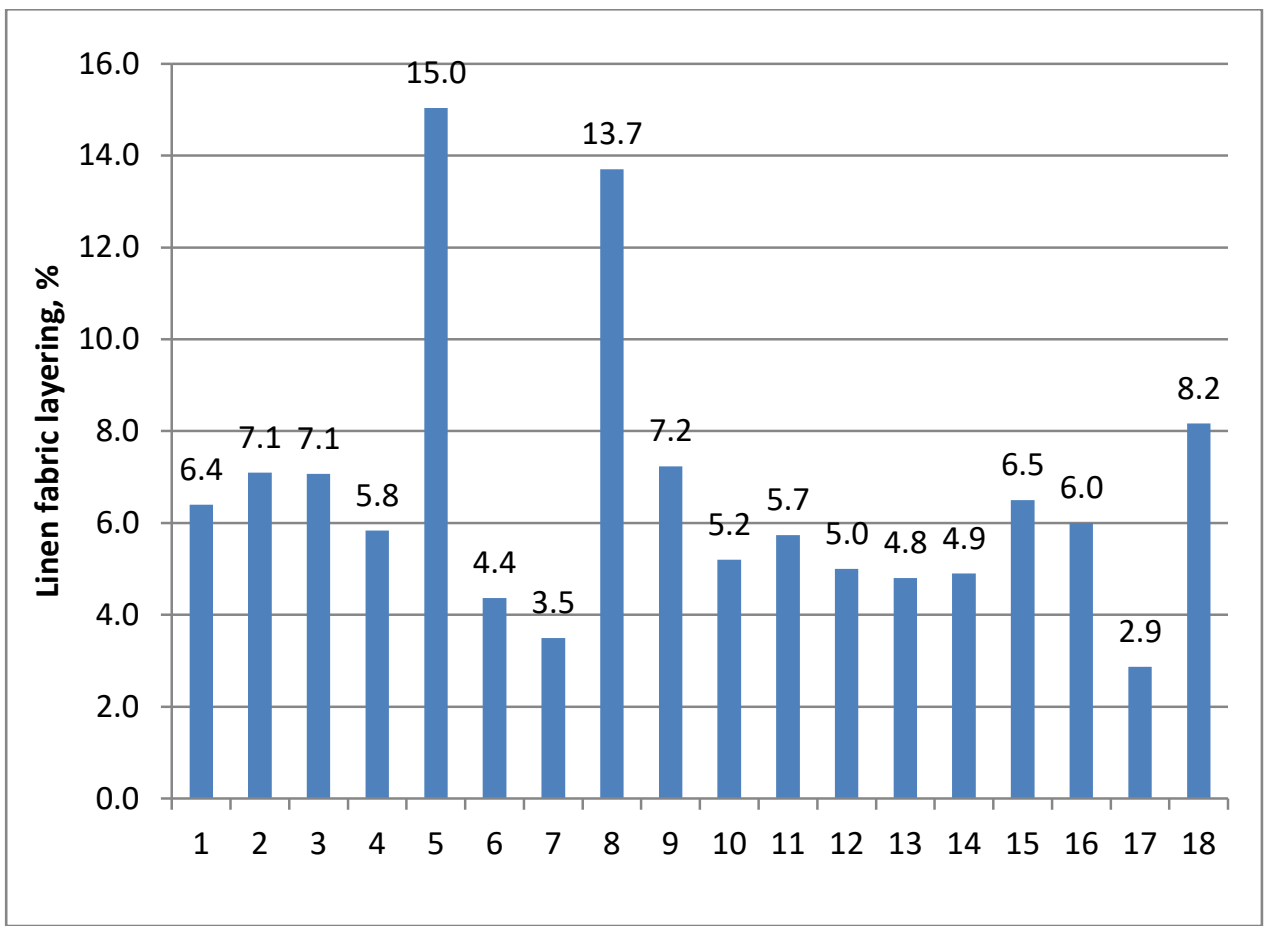

\section{Ground cover catch crop options (18 - control)}

Fig. 3. The intensity of the loss of linen on plots with the cultivation of various ground cover crops, $\%$

When growing oats in a pure form - option № 8, the activity of cellulose-decomposing bacteria was practically at the same level as in option №5, however, the intensity of decomposition of linen was maximum in the lower layer of $20-30 \mathrm{~cm}$. So, as a result of growing vetch in a mixture with winter rye, the activity of soil biota increased 2.2 times in comparison with plot №1 (winter rye), which was reflected in a greater degree of loss of linen (up to $15 \%$ ) than in sowing winter rye with monoculture. (fig. 4)

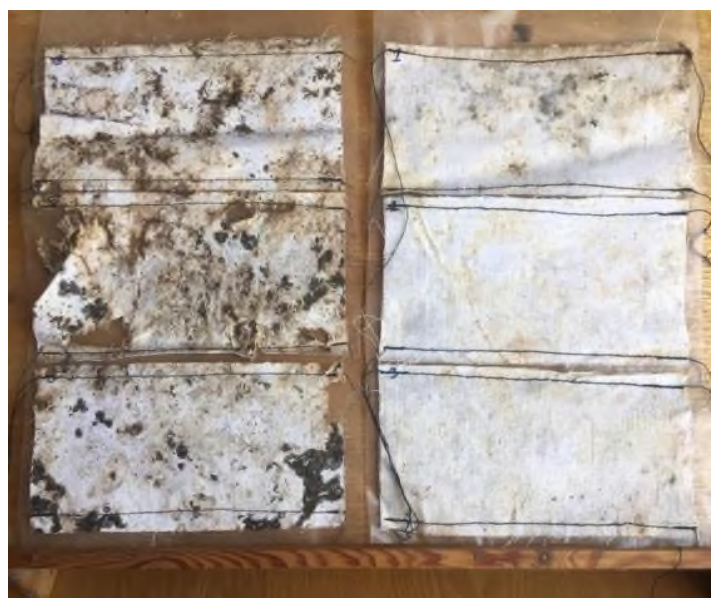

A)

B)

Fig. 4. Manifestation of the biological activity of the soil in the $0-30 \mathrm{~cm}$ layer during the cultivation of various ground cover crops. A) in a mixture of winter rye + vicia, B) winter rye. 
Thus, in terms of the biological activity of southern carbonate low-humus chernozems, more optimal conditions for the functioning of the microbial cenosis with the predominant participation of cellulose-decomposing bacteria are formed when oats and vetch are grown in a mixture with rye. Consequently, energy-saving No-till technologies in combination with the cultivation of ground cover crops can serve as one of the radical means of preserving and increasing soil fertility.

\section{Conclusion}

1. The cultivation of intermediate ground cover crops in the summer period made it possible to maintain the main agrophysical indicators of the fertility of the arable layer ( 0 $30 \mathrm{~cm}$ ) of southern carbonate low-humus chernozems at the optimum level.

2. Winter crops when grown in intermediate ground cover crops in 1-, 2- and 3-component mixtures provided a yield of green mass 1.8-2.1 times less than spring crops, and 3.6-4.1 times less multicomponent spring mixes consisting of 5-, 8-, 10- and 13-crops. When the maximum possible biomass of spring crops was obtained in the conditions of the Piedmontsteppe zone of Crimea, by the end of their growing season, $30-33 \mathrm{~kg}$ of nitrogen, $4-5.9 \mathrm{~kg}$ of phosphorus and 13.9-16.7 kg were recorded in the aboveground part of plants and in the root system. potassium per hectare of crops.

3 . In the studies, both an increase in cellulolytic activity in comparison with the control area and a decrease were observed. Significant differences were noted only in variants № 5 (rye with vetch) and № 8 (oats), where, in the arid conditions of August 2019, the percentage of linen loss was recorded at the maximum.

4. The introduction of AMG inoculum with vetch seeds did not affect the development of vesicles, despite the fact that vetch roots were maximally densely populated by mycorrhizal fungi with significant indicators of both the incidence of mycorrhizal colonization (MC) and its development intensity inside the roots and the abundance of arbuscules. With the use of AMG in oat plants, a significant increase in the intensity of MC was noted by $6.8 \%$, and the abundance of arbuscules by 3.9 times. Lentils, flax and sunflower plants respond in a similar way to the addition of AMG.

\section{References}

1. A. Fiorini, S. C. Maris, D. Abalos, S. Amaducci, V. Tabaglio. Combining no-till with rye (Secale cereale L.) cover crop mitigates nitrous oxide emissions without decreasing yield, Soil and Tillage Research, 196 (2020) https://doi.org/10.1016/j.still.2019.104442

2. N. J. Sithole, L. S. Magwaza. Long-term changes of soil chemical characteristics and maize yield in no-till conservation agriculture in a semi-arid environment of South Africa, Soil and Tillage Research, $194 \quad$ (2019) https://doi.org/10.1016/j.still.2019.104317

3. A. S. Nascente, Y. C. Li, C. A. C. Crusciol, Cover crops and no-till effects on physical fractions of soil organic matter, Soil and Tillage Research, 130, 52-57 (2013) https://doi.org/10.1016/j.still.2013.02.008

4. B. C. Liang, A. J. VandenBygaart, J. D. MacDonald, D. Cerkowniak, B. G. McConkey, R. L. Desjardins, D. A. Angerse, Revisiting no-till's impact on soil organic carbon storage in Canada, Soil and Tillage Research, 198 (2020) https://doi.org/10.1016/j.still.2019.104529

5. N. J. Sithole, L. S. Magwaza, G. R. Thibaudc. Long-term impact of no-till conservation agriculture and $\mathrm{N}$-fertilizer on soil aggregate stability, infiltration and distribution of $\mathrm{C}$ 
in different size fractions, Soil and Tillage Research, 190, 147-156 (2019) https://doi.org/10.1016/j.still.2019.03.004

6. E. Pareja-Sánchez, D. Plaza-Bonilla, M. C. Ramos, J. Lampurlanés, J. Álvaro-Fuentes, C. Cantero-Martínez, Long-term no-till as a means to maintain soil surface structure in an agroecosystem transformed into irrigation, Soil and Tillage Research, 174, 221-230 (2017). https://doi.org/10.1016/j.still.2017.07.012

7. I. Aziz, T. Mahmood, K. R. Islam, Effect of long term no-till and conventional tillage practices on soil quality, Soil and Tillage Research, 131, 28-35 (2013) https://doi.org/10.1016/j.still.2013.03.002

8. C. dos R. Ferreira, E. Carvalho da S. Neto, M. G. Pereira, J. do N. Guedes, J. S. Rosset, L. H. C. dos Anjos, Dynamics of soil aggregation and organic carbon fractions over 23 years of no-till management, Soil and Tillage Research, 198 (2020) https://doi.org/10.1016/j.still.2019.104533

9. C. R. Wuaden, R. S. Nicoloso, E. C. Barros, R. A. Grave, Early adoption of no-till mitigates soil organic carbon and nitrogen losses due to land use change, Soil and Tillage Research, 204 (2020) https://doi.org/10.1016/j.still.2020.104728

10. R. J. Lopez-Bellido, V. Muñoz-Romero, R. Fuentes-Guerra, P. Fernandez-Garcia, L. Lopez-Bellido, No-till: A key tool for sequestering $\mathrm{C}$ and $\mathrm{N}$ in microaggregates on a Mediterranean Vertisol, Soil and Tillage Research, 166, 131-137 (2017) https://doi.org/10.1016/j.still.2016.09.012

11. Z. Du, T. Ren, C. Hu, Q. Zhang, Transition from intensive tillage to no-till enhances carbon sequestration in microaggregates of surface soil in the North China Plain, Soil and Tillage Research, 146, 26-31 (2015) https://doi.org/10.1016/j.still.2014.08.012

12. L. Gristina, S. Keesstra, A. Novara, No-till durum wheat yield success probability in semi arid climate: A methodological framework, Soil and Tillage Research, 181, 29-36 (2018) https://doi.org/10.1016/j.still.2018.04.002

13. K. Skaalsveen, J. Ingram, L. E.Clarke, The effect of no-till farming on the soil functions of water purification and retention in north-western Europe: A literature review, Soil and Tillage Research, 189, 98-109 (2019) https://doi.org/10.1016/j.still.2019.01.004

14. B. D. Soane, B. C. Ball, J. Arvidsson, G. Basch, F. Moreno, J. Roger-Estrade, No-till in northern, western and south-western Europe: A review of problems and opportunities for crop production and the environment, Soil and Tillage Research, 118, 66-87 (2012) https://doi.org/10.1016/j.still.2011.10.015

15. E. J. Didoné, J. P. G. Minella, O. Evrard, Measuring and modelling soil erosion and sediment yields in a large cultivated catchment under no-till of Southern Brazil, Soil and Tillage Research, 174, 24-33 (2017) https://doi.org/10.1016/j.still.2017.05.011

16. O. Tomashova, Efficiency of cultivation of intermediate cover crops as a biological element of the fertilizer system at no-till in the Crimea / Olga Tomashova, Nicolay Osenniy, Aleksandr Ilyin, Lubov Veselova. XIII International Scientific and Practical Conference "State and Prospects for the Development of Agribusiness. INTERAGROMASH 2020”, 26-28 (Rostovon-Don, Russia, February, 2020)

17. S. F. Abdurashytov, New arbuscular mycorrhizal fungi associations from soils of crimean steppe, 78(1), 72-79 (2016) 